\title{
Investigating the effects of two novel 4-MMPB analogs as potent lipoxygenase inhibitors for prostate cancer treatment
}

Sonia Iranpour ${ }^{1 \dagger}$, Aseel Kamil Mohammed Al-Mosawi ${ }^{1,2 \dagger}$, Ahmad Reza Bahrami ${ }^{1,3}$, Hamid Sadeghian ${ }^{4}$ and Maryam M. Matin ${ }^{1,5^{*}}$ (D)

\begin{abstract}
Background: Lipoxygenases are one of the critical signaling mediators which can be targeted for human prostate cancer (PC) therapy. In this study, 4-methyl-2-(4-methylpiperazinyl)pyrimido[4,5-b]benzothiazine (4-MMPB) and its two analogs, 4-propyl-2-(4-methylpiperazinyl)pyrimido[4,5-b]benzothiazine (4-PMPB) and 4-ethyl-2-(4-methylpiperazinyl)pyrimido[4,5-b]benzothiazine (4-EMPB), were proposed to have anti-tumor properties in prostate cancer.

Methods: After synthesizing the compounds, cytotoxic effects of 4-MMPB and its two analogs against PC-3 cancerous and HDF normal cells were investigated by 3-[4,5-dimethylthiazol-2-yl]-2,5-diphenyltetrazolium bromide (MTT) assay and then mechanism of cell death was assessed by flow cytometry. Finally, the anti-tumor effects of the mentioned compounds were investigated in an immunocompromised C57BL/6 mouse model.

Results: 4-PMPB and 4-EMPB had similar anti-cancer effects on PC-3 cells as compared with 4-MMPB, while they were not effective on normal cells. Moreover, apoptosis and ferroptosis were the main mechanisms of induced cell death in these cancerous cells. Furthermore, in vivo results indicated that both analogs had similar anti-cancer effects as 4-MMPB, leading to delayed tumor growth without any noticeable side effects in weight loss and histological investigations.
\end{abstract}

Conclusion: Thus, our results suggest that specific targeting of lipoxygenases via 4-MMPB analogs can be considered as a treatment of choice for PC therapy, although it requires further investigations.

Keywords: Prostate cancer, Lipoxygenases, Chemotherapy, Targeted therapy

\section{Background}

Cancer is considered as a serious concern affecting the health of all human societies. Prostate cancer (PC) is the most common malignancy in males worldwide, representing the second leading cause of mortality [1]. Various environmental factors such as lifestyle, physical activity,

\footnotetext{
*Correspondence: matin@um.ac.ir

†Sonia Iranpour and Aseel Kamil Mohammed Al-mosawi contributed equally to this work

${ }^{1}$ Department of Biology, Faculty of Science, Ferdowsi University of Mashhad, Mashhad, Iran

Full list of author information is available at the end of the article
}

obesity and dietary habits, particularly high intake of saturated fats, have been related to an increased risk of PC [2]. Arachidonic acid (AA), one of the most important polyunsaturated fatty acids (PUFAs), constitutes an essential part of our diet and is found in meat, egg and dairy products [3]. This important fatty acid is required to maintain normal physiological functions, including tissue regeneration, cell membrane fluidity [4] and immune response [5]. However, excessive consumption of this fatty acid has an important role in cancer development [6] and this link has been established in numerous studies $[7,8]$. For example, experiments on mouse

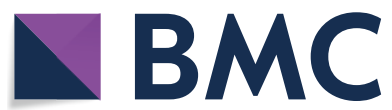

(c) The Author(s) 2021. This article is licensed under a Creative Commons Attribution 4.0 International License, which permits use, sharing, adaptation, distribution and reproduction in any medium or format, as long as you give appropriate credit to the original author(s) and the source, provide a link to the Creative Commons licence, and indicate if changes were made. The images or other third party material in this article are included in the article's Creative Commons licence, unless indicated otherwise in a credit line to the material. If material is not included in the article's Creative Commons licence and your intended use is not permitted by statutory regulation or exceeds the permitted use, you will need to obtain permission directly from the copyright holder. To view a copy of this licence, visit http://creativeco mmons.org/licenses/by/4.0/. The Creative Commons Public Domain Dedication waiver (http://creativecommons.org/publicdomain/ zero/1.0/) applies to the data made available in this article, unless otherwise stated in a credit line to the data. 
models supported the effects of high-fat diet (HFD) in development and progression of prostate cancer $[9,10]$. Moreover, it has been demonstrated that HFD results in increased tumor weight and number of intestinal polyps in mice $[11,12]$. Similar effects have been reported in mouse models with breast cancer $[13,14]$.

Human lipoxygenases (LOXs) are a family of non-heme iron based enzymes that are involved in the metabolism of AA and other PUFAs into biologically active metabolites [15]. So far, several human LOX isoforms including 15-LOX-1, 15-LOX-2, 5-LOX and 12-LOX have been identified and categorized based on enzymatic characterization [16]. For example, 15-LOXs introduce the oxygen at carbon 15 of AA backbone. Two distinct human 15-LOXs are widely distributed in various tissues, exhibiting different substrate preferences. 15-LOX-1, one of the critical enzymes of mammalian LOX family, is physiologically overexpressed in specific cancerous tissues such as prostate [17] and renal cancer [18], while it is poorly expressed in colorectal $[19,20]$, lung [21], esophageal [22] and bladder cancers [23] as well as chronic myeloid leukemia [24]. Thus, 15-LOX-1 is involved in both tumor promotion and suppression depending on the type of cancer. This enzyme predominantly metabolizes linoleic acid (LA) to 13S-hydroperoxyoctadecadienoic acid (13S-HpODE), but also metabolizes AA to $12 S$ - and 15S-hydroperoxyeicosatetraenoic acid (15S-HpETE) [25]. 15-LOX-2 is constitutively expressed in healthy normal prostate tissue [17] while it is down regulated in prostate [26], lung [27] and esophageal cancers [28]. In contrast to 15 -LOX-1, 15-LOX-2 preferentially catalyzes AA to $15 S$-HpETEs and poorly metabolizes LA [29]. Similarly, 5-LOX and 12-LOX utilize AA to synthesize 5S-HpETE and $12 S$-HpETE, respectively $[30,31]$ and their expression is linked to PC spreading and metastasis [32]. In this context, blocking overexpressed LOX enzymes in PC could be one of the promising targets facilitating drug discovery and treatment. There are several studies reporting different compounds with significant inhibitory effects on 15-LOX-1. Coumarin-based inhibitors, such as 8-farnesyloxycoumarin [33], 5-farnesyloxycoumarin [34] and 7-farnesyloxycoumarin [35] exhibited inhibitory potency against 15-LOX-1 with half maximal inhibitory concentration $\left(\mathrm{IC}_{50}\right)$ values of $2.64,8.32$ and $11.8 \mu \mathrm{M}$, respectively. Furthermore, the inhibitory activities of stylosin and its derivatives have also been shown on soybean LOX-1 [36]. These compounds exerted their anti-cancer effects in PC cells via induction of apoptosis. In addition, indole-based inhibitors, such as 14d [37], indolylpyrazoline (4b) [38] and 9c (i472) [39] are members of another group of potent 15-LOX-1 inhibitors. Sarveswaran et al. [40], treated PC cells with MK591 as a specific chemical inhibitor of 5-LOX activity in order to induce apoptosis via down-regulation of protein kinase C-epsilon (PKCe) and disruption of c-Myc signaling [41]. Moreover, it has been shown that inhibition of 12-LOX activity markedly sensitizes PC cells to radiation both in vivo and in vitro [42, 43]. Recent studies have demonstrated that ferroptotic pathway as another type of programmed cell death can be mediated via LOXs in some contexts to eradicate cancers $[44,45]$.

Considering the association between lipoxygenase activity and PC development, the inhibition of these pathways provides an interesting therapeutic strategy to suppress tumorigenesis and malignant growth. It has been shown that 4-methyl-2-(4 methylpiperazinyl) pyrimido[4,5-b]benzothiazine (4-MMPB) as a heterocyclic compound, functions as an effective and specific 15-lipoxygenase inhibitor with an $\mathrm{IC}_{50}$ value of $18 \mu \mathrm{M}$ [46]. Moreover, its analog, 4-propyl-2-(4-methylpiperazinyl)pyrimido[4,5-b]benzothiazine (4-PMPB), exhibited robust inhibitory potency against soybean LOX-1 with an $\mathrm{IC}_{50}$ value of $9 \mu \mathrm{M}$ [47]. In this study, inhibitory potency of the other analog with ethyl moiety at position 4 of pyrimido benzothiazine (4-ethyl-2-(4-methylpiperazinyl)pyrimido[4,5-b]benzothiazine (4-EMPB)) against lipoxygenases was also investigated (Table 1). We aimed to test the anti-cancer effects of 4-PMPB and 4-EMPB on PC cells both in vitro and in vivo. Cytotoxicity and anticancer properties of the three compounds were evaluated on cancerous (human prostate cancer cell line; PC-3) and normal (human dermal fibroblast; HDF) cells. Moreover, the mechanism of cell death was assessed via FITCannexin $\mathrm{V}$ and propidium iodide (PI) staining. Tumor inhibitory effects of the compounds were then evaluated in immunocompromised C57BL/6 mice bearing human PC-3 cells.

\section{Methods}

All chemical reagents and solvents were purchased from Merck (Darmstadt, Germany) and used as received without further purification. 3-[4,5-dimethylthiazol-2-yl]-2,5 diphenyltetrazolium bromide (MTT) and trypsin-EDTA were purchased from Tinab Shimi (Mashhad, Iran). Roswell Park Memorial Institute 1640 (RPMI 1640) culture medium and Dulbecco's modified Eagle's medium (DMEM) were bought from Gibco (Scotland, UK). Fetal bovine serum (FBS; Schwalbach, Germany), and penicillin-streptomycin were obtained from Gibco (Loughborough, UK). Soybean LOX-1 (L1; type I-B; EC 1,13,11,12) and linoleic acid (L1376) were bought from SigmaAldrich (St. Louis, USA). Itraconazole and co-amoxiclav were purchased from Tehran Darou Pharmaceutical Co. and AFA Chemi, Pharmaceutical Co. (Tehran, Iran), respectively. 
Table 1 Chemical characteristics of 4-MMPB and its analogs

4-Ethyl-2-(4-methylpiperazinyl)pyrimido[4,5-b]benzothiazine (4-EMPB)

\section{Synthesis of compounds}

4-MMPB and 4-PMPB were synthesized as previously described $[46,47]$. The new analog 4-EMPB was similarly synthesized via the following procedure (as illustrated in Fig. 1).

\section{2-[(5-Bromo-2-chloro-6-ethylpyrimidin-4-yl)sulfanyl] aniline (2)}

To a solution of 5-bromo-2,4-dichloro-6-ethylpyrimidine 1 (CAS No. 1373331-48-6) (2.54 g, $10 \mathrm{mmol}$ ) and triethylamine $(1.2 \mathrm{~g})$ in chloroform $(30 \mathrm{ml}), 2$-aminothiophenol (1.25 g, $10 \mathrm{mmol})$ was added dropwise with vigorous stirring over a minute. Solvent was removed and the residue was washed with warm water and then crystallized from ethanol (2.6 g, 83\% yield, Melting Point: $153{ }^{\circ} \mathrm{C}$ (dec). IR: 3300, $3432 \mathrm{~cm}^{-1},{ }^{1} \mathrm{H}$ NMR $\left(\mathrm{CDCl}_{3}\right): 1.27\left(\mathrm{t}, 3 \mathrm{H}, \mathrm{CH}_{3}\right)$, 2.87 (q, $2 \mathrm{H}, \mathrm{CH}_{2}$ ), 4.30 (broad, $2 \mathrm{H}, \mathrm{NH}_{2}$ ), 6.77-7.43 (m, $4 \mathrm{H}),{ }^{13} \mathrm{C} \mathrm{NMR}\left(\mathrm{CDCl}_{3}\right): 14.1,29.8,114.4,117.5,118.5$, $120.4,128.0,128.7,147.3,157.4,161.5,162.8)$.

\section{4-ethyl-2-(4-methylpiperazinyl)pyrimido[4,5-b] benzothiazine (4-EMPB) (4)}

A mixture of 2-[(5-bromo-2-chloro-6-ethylpyrimidin4-yl)sulfanyl]aniline $2(3.43 \mathrm{~g}, 10 \mathrm{mmol})$ and 4-methylpiperazin $(30 \mathrm{mmol})$ in ethanol $(20 \mathrm{ml})$ was heated under reflux for $5 \mathrm{~h}$. Water $(40 \mathrm{ml})$ was added to the solution and separated sticky liquid (intermediate 3) was dried at $80{ }^{\circ} \mathrm{C}$ for an hour and immediately utilized without purification. Sodium amide $(1.2 \mathrm{~g}, 30 \mathrm{mmol})$ was added to stirred solution of the intermediate 3 in acetonitrile $(30 \mathrm{ml})$, and then heated under reflux condition $(3 \mathrm{~h})$.
The solvent was removed and a solution of $2 \%$ acetic acid $(20 \mathrm{ml})$ was added to the residue and filtered. Then the residue was crystallized from benzene to give 4-ethyl2-(4-methylpiperazinyl)pyrimido[4,5-b]benzothiazine (4-EMPB) (4) as a yellow powder (55\% yield). Melting Point: $171-173{ }^{\circ} \mathrm{C}$; IR: $3348 \mathrm{~cm}^{-1},{ }^{1} \mathrm{H}$ NMR: $\left(\mathrm{CDCl}_{3}\right)$ $1.26(\mathrm{t}, 3 \mathrm{H}, \mathrm{CH} 3), 2.34\left(\mathrm{~m}, 7 \mathrm{H}, \mathrm{CH}_{3} \mathrm{~N}\left(\mathrm{CH}_{2}\right)_{2}\right), 2.86(\mathrm{t}$, $\left.2 \mathrm{H}, \mathrm{CH}_{2}\right), 3.73\left(\mathrm{t}, 4 \mathrm{H}, 2\left(\mathrm{CH}_{2} \mathrm{~N}\right)\right), 6.92(\mathrm{dd}, 2 \mathrm{H}, \mathrm{C} 7 \mathrm{H} \&$ $\mathrm{C} 8 \mathrm{H}), 7.35$ (d, 1H, C6H), 8.20-8.42 (d, 2H, C9H \& NH); 13C NMR: $\left(\mathrm{CDCl}_{3}\right)$ 14.1, 23.9, 39.5, 44.1, 46.7, 56.4, 94.7, 120.5, 122.7, 124.1, 131.1, 136.7, 141, 155.6, 159.6, 167.0; Elemental analysis of $\mathrm{C}_{17} \mathrm{H}_{21} \mathrm{~N}_{5} \mathrm{~S}$ : Calculated: $\mathrm{C}$, 62.36; $\mathrm{H}$, 6.46; N, 21.39; S, 9.79. Found: C, 62.41; H, 6.49; N, 21.27; $\mathrm{S}, 9.72$.

\section{Enzyme inhibitory assessment}

Linoleic acid and two assay solutions (A and B) were prepared in advance. Solution A was $50 \mathrm{mM}$ 3-(dimethylamino)benzoic acid (DMAB) in $100 \mathrm{mM}$ phosphate buffer (pH 7.0). Solution B was a mixture of $10 \mathrm{mM}$ 3-methyl2-benzothiazolinonehydrazone hydrochloride (MBTH; $3 \mathrm{ml}$ ), and hemoglobin $\left(5 \mathrm{mg} \mathrm{ml}^{-1}, 3 \mathrm{ml}\right)$ in $50 \mathrm{mM}$ phosphate buffer at pH $5.0(25 \mathrm{ml})$. A linoleic acid solution was prepared by mixing $5.6 \mathrm{mg}$ linoleic acid with $0.5 \mathrm{ml}$ methanol and then diluted with $100 \mathrm{mM} \mathrm{KOH}$ to a final volume of $5 \mathrm{ml}(4 \mathrm{mM})$. In the assay, a solution of inhibitors in dimethyl sulfoxide (DMSO) $(12.5 \mu \mathrm{l})$, soybean LOX-1 (4000 units $\mathrm{ml}^{-1}$ in $50 \mathrm{mM}$ phosphate buffer $\mathrm{pH}$ 7.0; $25 \mu \mathrm{l})$, and phosphate buffer, $\mathrm{pH} 7.0$ (50 mM; $435 \mu \mathrm{l})$ were mixed in 48-well plates, and pre incubation was carried out for $10 \mathrm{~min}$ at $30^{\circ} \mathrm{C}$. A control test was performed 
<smiles>CCc1nc(Cl)nc(Cl)c1Br</smiles>

1<smiles>Nc1ccccc1S</smiles>

2<smiles>[Z]Cc1nc(Cl)nc(Sc2ccccc2N)c1Br</smiles><smiles>CCc1nc(N2CCN(C)CC2)nc(Sc2ccccc2N)c1Br</smiles><smiles>CCc1nc(N2CCN(C)CC2)nc2c1Nc1ccccc1S2</smiles>

4 (4-EMPB)

$\mathrm{NaNH}_{2}$

3

Fig. 1 Synthetic pathway of 4-EMPB

with the same volume of DMSO. After the pre incubation, linoleic acid solution $(25 \mu \mathrm{l})$ was added to start the peroxidation reaction at $30^{\circ} \mathrm{C}$, and $10 \mathrm{~min}$ later, solution A $(135 \mu \mathrm{l})$ and then solution $\mathrm{B}(65 \mu \mathrm{l})$ were added to start the color formation. After $3 \mathrm{~min}, 100 \mu \mathrm{l}$ of a $2 \%$ sodium dodecyl sulphate (SDS) solution was added to terminate the reaction. The absorbance at $598 \mathrm{~nm}$ was compared with the control. These experiments were performed in triplicate and the data were analyzed using GraphPad Prism 6.0 (San Diego, USA).

\section{Preparing different solutions of compounds for cell culture} Two mg of each compound was dissolved in $100 \mu \mathrm{l}$ hydrochloric acid $(\mathrm{HCl} 0.3 \mathrm{~N})$ to make a primary stock solution. Different concentrations $\left(1.56-50 \mu \mathrm{g} \mathrm{ml}^{-1}\right)$ were then prepared by serial dilution from the primary stock solution and further diluted in the culture medium. Moreover, culture medium containing $0.25 \% \mathrm{HCl} 0.3 \mathrm{~N}$ was used as a negative control in all experiments for a better evaluation.

\section{Cell culture}

PC-3 cells were obtained from Pasteur Institute (Tehran, Iran) and routinely cultured in RPMI 1640 supplemented with $10 \%$ FBS. In order to investigate the toxicity of the compounds on normal cells, in vitro experiments were also performed on HDF cells. These cells were kindly provided by Academic Center for Education, Culture and Research (ACECR, Mashhad, Iran) and grown in DMEM supplemented with $10 \%$ FBS. Both cell lines were kept at $37^{\circ} \mathrm{C}$ containing $5 \% \mathrm{CO}_{2}$ in a humidified incubator.

\section{Cytotoxicity assay}

The MTT reduction assay is a standard quantitative method to evaluate cytotoxicity. This assay measures cellular dehydrogenases, and is considered as an easy, safe and highly reproducible method. Viable cells reduce yellow tetrazolium salt to purple formazan crystals and thus the color change serves as a marker reflecting cell viability [48]. 
PC-3 and HDF cells were seeded in 96-well plates (NEST, China) at a density of 6000 and 8000 cells per well, respectively and incubated at $37{ }^{\circ} \mathrm{C}$ with $5 \% \mathrm{CO}_{2}$. Next day, the media were changed and both cell lines were treated with various concentrations $\left(1.56-50 \mu \mathrm{g} \mathrm{ml}^{-1}\right.$ ) of the compounds and cisplatin. Experiments were carried out in triplicate for 4-PMPB, 4-EMPB and 4-MMPB as well as cisplatin as a positive control. After 24, 48 and $72 \mathrm{~h}$ of treatments, $20 \mu \mathrm{l}$ MTT solution $\left(5 \mathrm{mg} \mathrm{ml}^{-1}\right.$ in PBS; phosphate buffered saline) was added to each well, and cells were incubated in the dark for $3-4 \mathrm{~h}$. The media were then removed and purple crystals were dissolved in $160 \mu \mathrm{l}$ DMSO. The absorbance in each well was measured at $540 \mathrm{~nm}$ as reference wavelength in an enzymelinked immunosorbent assay (ELISA) reader (Awareness Technology, USA) and relative optical density (OD) values were recorded. The percentage of viable cells was calculated using the following equation [49]:

$$
\text { Cell viability }(\%)=100 \times\left[\left(\mathrm{OD}_{\text {mean }} \text { of treated cells }-\mathrm{OD}_{\text {mean }} \text { blank }\right) /\right.
$$

$\left(\mathrm{OD}_{\text {mean }}\right.$ of negative control cells $(\mathrm{HCl} 0.3 \mathrm{~N})$ $-\mathrm{OD}_{\text {mean blank)]. }}$

\section{Flow cytometric analysis}

To determine the mechanism of cell death induced by 4-MMPB analogs, flow cytometry was employed using the Annexin V-FITC kit with PI (BioLegend, San Diego, USA) according to the manufacturer's instructions. We performed co-treatment experiments with the compounds and a ferroptosis inhibitor $\left(\mathrm{IC}_{50}\right.$ values of 4-PMPB +, 4-EMPB +, and 4-MMPB + deferoxamine $(80 \mu \mathrm{M}))$ on $\mathrm{PC}-3$ cells, to distinguish between ferroptosis and apoptosis mechanisms [50]. In order to evaluate the apoptosis mechanism, cells were treated with the $1 / 2 \times \mathrm{IC}_{50}$ and $\mathrm{IC}_{50}$ values of 4-PMPB, 4-EMPB, 4-MMPB, and cisplatin for $24 \mathrm{~h}$. Then the cells were collected by trypsinization ( $0.25 \%$ trypsin- $1 \mathrm{mM}$ EDTA), washed twice with PBS, followed by centrifugation, and resuspended in a binding buffer. Samples were stained with Annexin V-FITC/ PI followed by 15 min incubation at room temperature. Finally, cells were subjected to flow cytometry (BD Accuri C6, San Jose, USA) and the data were analyzed by FlowJo 7.6.1 software (Ashland, USA). Moreover, $\mathrm{PC}-3$ cells treated with $0.3 \mathrm{~N} \mathrm{HCl}$ were used as a control to eliminate the effects of solvent.

\section{Anti-cancer evaluation of compounds on a PC-3 xenograft tumor model}

The animal experiments were approved and conducted in accordance with Animal Ethics Committee of Ferdowsi University of Mashhad (FUM) (IR.UM.REC.1399.001). C57BL/6 mice were inbred in an animal house at FUM and maintained under pathogen-free conditions. Immunosuppression of male C57BL/6 mice (4-6 weeks old) was carried out according to the protocol described by Jivrajani et al. [51]. However, in this study, for immunosuppression ketoconazole and ampoxin drugs were replaced with itraconazole and co-amoxiclav. After completion of this procedure, the total white blood cell (WBC) and lymphocyte counts were evaluated to confirm the immunosuppression protocol.

The PC-3 tumor model was generated by subcutaneous injection of $3 \times 10^{6}$ cells in $100 \mu \mathrm{l}$ RPMI 1640 into the right flank of the immunocompromised mice. When the tumor volume reached $100-200 \mathrm{~mm}^{3}$, the animals were randomly divided into 9 groups ( $\mathrm{n}=8$ per group) and treated with: 1) PBS as a negative control; 2) $\mathrm{HCl}(0.3 \mathrm{~N})$ as solvent control; 3) 4-PMPB (10 mg kg-1); 4) 4-РMPB (50 mg kg-1); 5) 4-EMPB (10 mg kg-1); 6) 4-ЕMPB (50 mg kg-1); 7) 4-MMPB (10 mg kg-1); 8) 4-МMPB (50 $\mathrm{mg} \mathrm{kg}^{-1}$ ) and 9) cisplatin as a positive control $\left(2 \mathrm{mg} \mathrm{kg}{ }^{-1}\right)$. The changes in tumor size and body weight were monitored every other day. The tumor volumes were calculated using the following formula [52]:

$$
\begin{aligned}
& \text { Tumor volume }\left(\mathrm{mm}^{3}\right) \\
& =(\text { Tumor length }) \times(\text { Tumor width })^{2} \times 0.5
\end{aligned}
$$

To validate the anti-tumor activity in different experimental groups, mice were sacrificed 15 days post treatment. Meanwhile, blood samples were collected and histological analyses were also performed to investigate the possible side effects. Hematological analyses were performed in an automated hematology analyzer (Sysmex XP-300; Lincolnshire, USA). The tissue slices were stained with hematoxylin and eosin (H\&E) and observed by an optical microscope (Olympus IX70; Tokyo, Japan).

\section{Statistical analysis}

All statistical analyses were carried out using GraphPad Prism software 6.0 (San Diego, USA). First the Kolmogorov-Smirnov test was performed to evaluate the normal distribution of the data. Then, differences between groups were assessed with Student's $t$-test (group pairs) or one-way ANOVA (multiple groups) followed by Tukey multiple comparison tests. Experiments were performed in triplicate and data are presented as mean \pm standard error or standard deviation as required. $p$-values $<0.05$ were considered as significant.

\section{Results \\ Enzyme activity assay}

Lipoxygenase inhibitory activity of 4-MMPB and its analogs was assessed on soybean LOX-1 and the inhibitory 
potencies $\left(\mathrm{IC}_{50}\right.$ values) of the mentioned compounds were calculated from their sigmoidal dose-response curves (Fig. 2). As expected, 4-EMPB decreased lipoxygenase activity by $\mathrm{IC}_{50}$ value of $14.3 \mu \mathrm{M}$, which falls between inhibitory potencies of 4-PMPB $\left(\mathrm{IC}_{50}=8.6 \mu \mathrm{M}\right)$ and 4-MMPB $\left(\mathrm{IC}_{50}=17.1 \mu \mathrm{M}\right)$.

\section{In vitro cell viability assay}

In present study, we first evaluated in vitro cytotoxicity and anti-cancer properties of 4-PMPB and 4-EMPB on PC-3 and HDF cells, and the results were compared with 4-MMPB as a potent 15-lipoxygenase inhibitor and cisplatin as a well-known chemotherapeutic drug. After exposing both cell lines to different concentrations of compounds, cell viability was determined by MTT assay and $\mathrm{IC}_{50}$ values were calculated. The $\mathrm{IC}_{50}$ values and dose-response curves are presented in Table 2 and Fig. 3, respectively. Dose-response curves indicated that 4-PMPB and 4-EMPB have similar anti-cancer effects on PC-3 cells as compared with 4-MMPB. As shown in Table 2, 4-PMPB, showed no obvious cytotoxicity on normal cells, while, 4-EMPB and 4-MMPB exhibited a weak cytotoxicity on HDF cells. Furthermore, cisplatin showed prominent cytotoxic effects on both prostate cancer and normal cells.

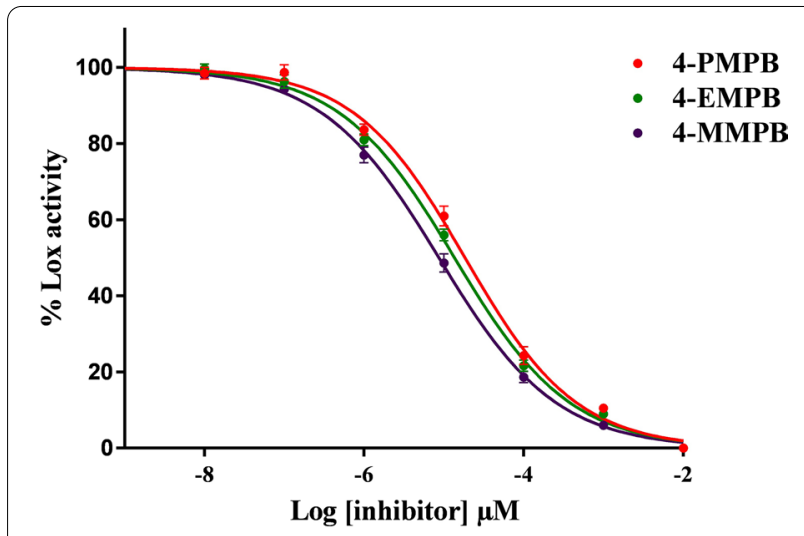

Fig. 2 Dose-response curves for soybean LOX-1 inhibition by 4-MMPB and its analogs. Data are expressed as mean $\pm S E M, n=3$

\section{Evaluating the mechanism of cell death}

To evaluate the mechanism of cell death, PC-3 cells cotreated with 4-PMPB, 4-EMPB, or 4-MMPB in combination with deferoxamine, a ferroptosis inhibitor, were assessed using Annexin V-FITC/ PI staining and compared with those treated with the compounds only. The results revealed that the population in Q2 (Annexin V positive/PI positive) was markedly decreased after cotreatment with deferoxamine as compared to those evaluated in the absence of this ferroptosis inhibitor. These observations suggest that 4-MMPB and its two analogs have probably induced both apoptosis and ferroptosis in PC-3 cells (Fig. 4). Flow cytometry-based quantification showed the percentage of early and late apoptotic/ ferroptotic cells $(\mathrm{Q} 3+\mathrm{Q} 2)$ increased from $0.133 \%$ in control to $52.38 \%, 60.9 \%, 41.5 \%$ and $67.8 \%$ in 4-PMPB-, 4-EMPB-, 4-MMPB-, and cisplatin- treated PC-3 cells, respectively, when treated with $\mathrm{IC}_{50}$ values of the compounds.

\section{In vivo anti-tumor effects of the compounds}

After administration of immunosuppression protocol, blood samples were collected and their parameters were compared with normal C57BL/6 mice. Significant reduction in $\mathrm{WBC}$, lymphocyte, and neutrophil counts $(p<0.0001)$ was confirmed in immunocompromised mice (Fig. 5). On day 11 after immunosuppression, PC-3 cells were injected subcutaneously. Immunocompromised mice bearing PC-3 tumors were then treated with PBS, $0.3 \mathrm{~N} \mathrm{HCl}$, 4-PMPB (10 and $50 \mathrm{mg} \mathrm{kg}^{-1}$ ), 4-EMPB (10 and $50 \mathrm{mg} \mathrm{kg}^{-1}$ ), 4-MMPB (10 and $50 \mathrm{mg} \mathrm{kg}^{-1}$ ), and cisplatin, and then their body weights and tumor volumes were measured every other day. As shown in Fig. 6a-c, tumor growth was effectively inhibited after treatment with high doses of 4-PMPB, 4-EMPB, and 4-MMPB. In contrast, tumors in control groups receiving $\mathrm{PBS}$ and $0.3 \mathrm{~N} \mathrm{HCl}$ grew markedly during the 15 days follow up period. Furthermore, the positive control group, receiving cisplatin, exhibited a significant decrease in tumor growth as compared with the controls and other experimental groups with lower doses. The results revealed that, there was no significant difference between tested compounds (4-PMPB, 4-EMPB) and 4-MMPB in tumor inhibition.

Table 2 Anti-proliferative activity of tested compounds on PC-3 and HDF cells during 24, 48, and $72 \mathrm{~h}$ of treatments

\begin{tabular}{|c|c|c|c|c|c|c|}
\hline \multirow[t]{2}{*}{ Compounds } & \multicolumn{3}{|c|}{$I C_{50}(\mu \mathrm{M}) \pm S D(P C-3)$} & \multicolumn{3}{|c|}{$I C_{50}(\mu \mathrm{M}) \pm S D(H D F)$} \\
\hline & $24 \mathrm{~h}$ & $48 \mathrm{~h}$ & $72 \mathrm{~h}$ & $24 \mathrm{~h}$ & $48 \mathrm{~h}$ & $72 \mathrm{~h}$ \\
\hline 4-PMPB & $122.303 \pm 2.618$ & $88.45 \pm 2.312$ & $57.58 \pm 2.123$ & $1641.10 \pm 0.075$ & $1443.73 \pm 0.055$ & $1028.86 \pm 0.139$ \\
\hline 4-EMPB & $107.44 \pm 6.17$ & $74.95 \pm 3.39$ & $48.99 \pm 6.76$ & $545.55 \pm 1.99$ & $361.70 \pm 2.29$ & $258.87 \pm 1.86$ \\
\hline 4-MMPB & $100.76 \pm 2.412$ & $55.55 \pm 1.980$ & $40.79 \pm 1.795$ & $331.42 \pm 3.332$ & $284.09 \pm 2.975$ & $185.61 \pm 2.805$ \\
\hline Cisplatin & $62.29 \pm 1.741$ & $51.53 \pm 1.425$ & $41.63 \pm 1.108$ & $153.42 \pm 2.89$ & $119.49 \pm 2.565$ & $71.09 \pm 3.337$ \\
\hline
\end{tabular}




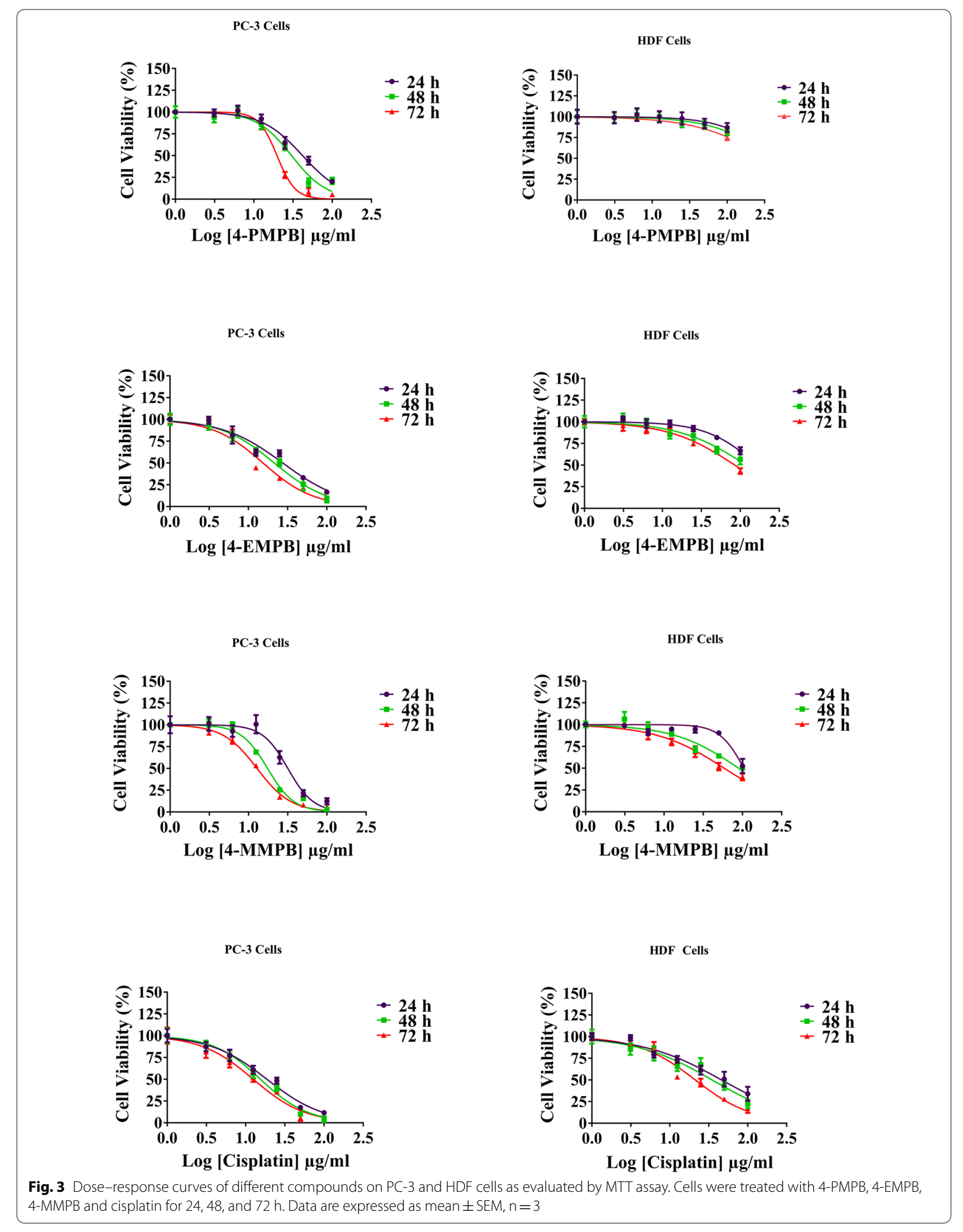




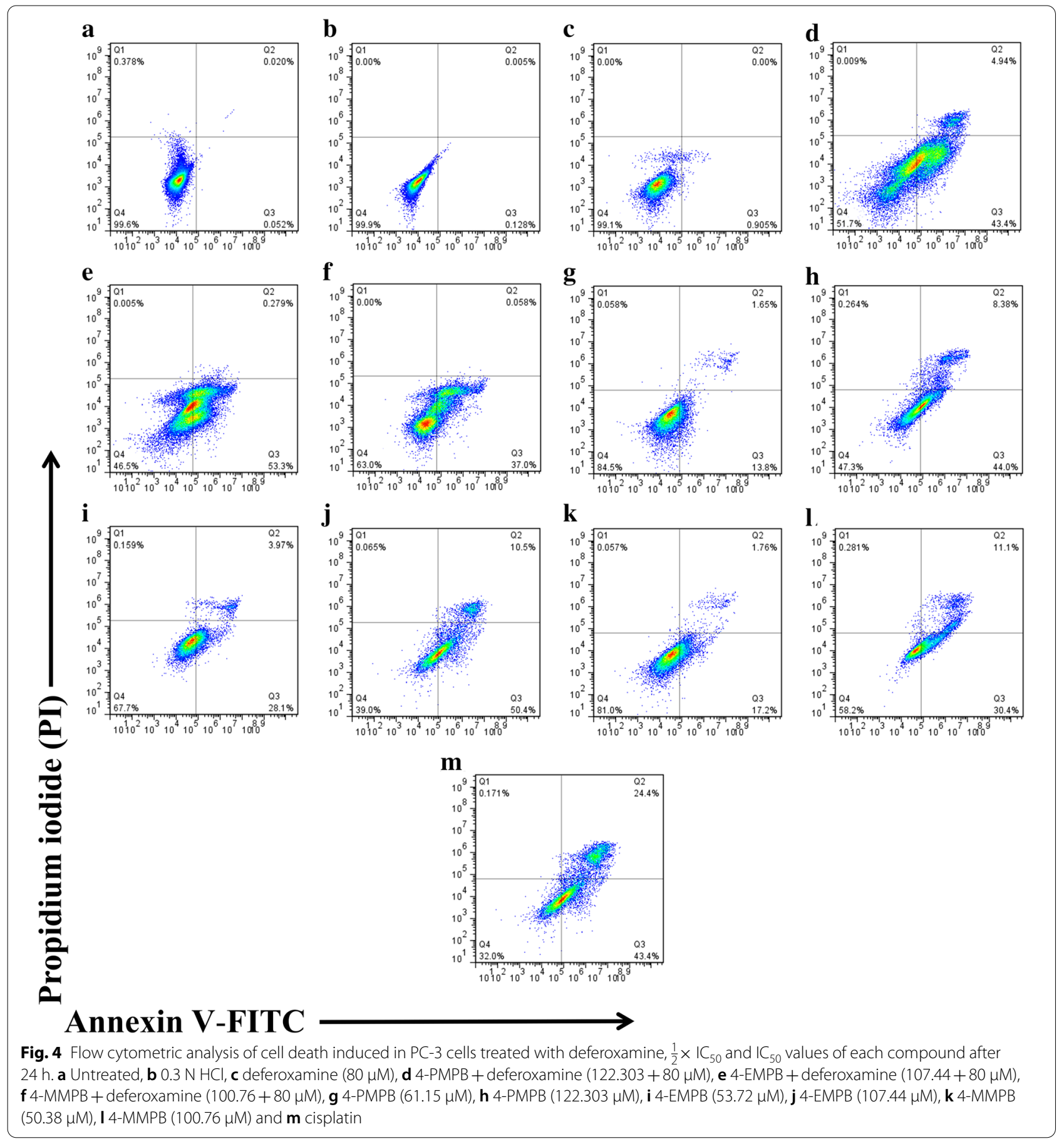

\section{In vivo side effects evaluation}

The side effects of the compounds were evaluated by measuring the body weights, hematological analyses, and $\mathrm{H} \& \mathrm{E}$ staining of different organs. Body weights of various groups were compared and as shown in Fig. 6d and e, the cisplatin treated group demonstrated the lowest body weights, which were significantly lower than other experimental groups $(p<0.01)$. However, no significant changes in body weights were observed between 4-PMPB- (10 and $\left.50 \mathrm{mg} \mathrm{kg}^{-1}\right)$, 4-EMPB- (10 and $\left.50 \mathrm{mg} \mathrm{kg}^{-1}\right)$ and 4-MMPB- (10 and $50 \mathrm{mg} \mathrm{kg}^{-1}$ ) treated groups.

To determine possible side effects of various treatments in vivo, biochemical parameters such as urea, aspartate transaminase (AST) and alanine aminotransferase (ALT) were evaluated in different experimental groups (Fig. 7). 


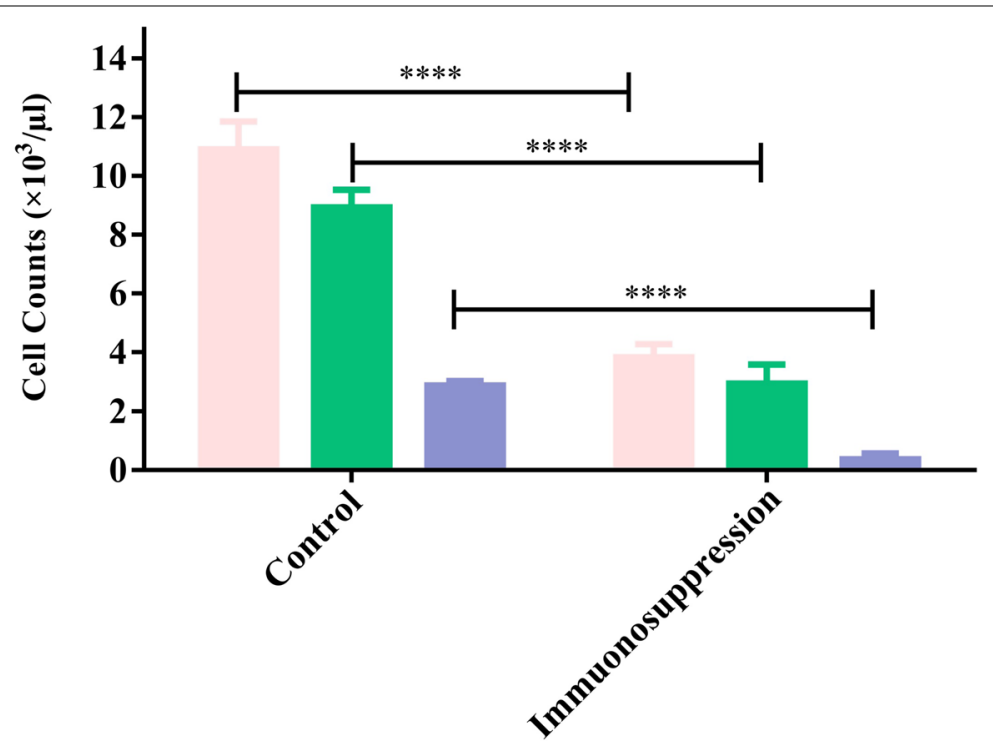

WBC
Lymphocytes
Neutrophils

Fig. 5 Effects of immunosuppression protocol on white blood cell (WBC), lymphocyte and neutrophil counts. Significant differences were observed between control and immunosuppression groups. Data are expressed as mean $\pm S D, n=3, * * * p<0.0001$

Urea levels did not change in all treatment groups as compared with the immunosuppressed group. Mice treated with 4-PMPB, 4-EMPB and 4-MMPB at concentrations of $50 \mathrm{mg} \mathrm{kg}^{-1}$ had significantly elevated AST and ALT levels compared with immunosuppressed control group. Similarly, the group treated with cisplatin had significantly increased serum liver enzymes compared to control group $(p<0.0001)$. Histological analysis showed no obvious tissue damages in major organs including liver, kidney, and spleen, following 4-PMPB, 4-EMPB, and 4-MMPB treatments. However, mild and local accumulation of inflammatory cells was noticed in cisplatin treated group (Fig. 8). Meanwhile, the tumor tissue treated with cisplatin and high doses of compounds exhibited a higher degree of cell death than the other experimental groups (Fig. 9). Apoptosis of tumor cells with nuclear and cytoplasmic condensation and also tumor necrosis were visualized in treated groups. However, further immunohistochemical analyses are required to confirm the exact type of cell death in tumor tissues.

\section{Discussion}

In recent years, cancer incidence rate has increased significantly especially in developing countries and discovering more effective treatments has emerged as a major concern. Chemotherapy is one of the conventional treatment modalities, which can increase patient's survival. However, therapeutic index can be decreased due to serious limitations of chemotherapy including drug resistance, poor specificity, and undesirable, long term side effects [53, 54]. Discovering cell signaling molecules which can trigger an apoptotic pathway in cancerous cells is crucial to improve therapeutic outcomes. Lipoxygenases are considered as a family of important signaling mediators that their overexpression is associated with tumor initiation and progression of prostate cancer [55]. Development of effective lipoxygenase inhibitors may successfully diminish cell proliferation in the tumor mass. An example of established 15-lipoxygenase inhibitors is 4-MMPB [46], which has been well documented in recent studies on PC-3 cells [33-36]. In this study, two 4-MMPB analogs, 4-PMPB and 4-EMPB, with inhibitory effects on lipoxygenase activity [46, 47] were employed and 4-PMPB indicated the most selective anti-proliferative effects as compared with the other two. The significantly lower cytotoxicity of these compounds on HDF cells can be attributed to the low expression of lipoxygenases in these normal cells [56, 57]. Considering the lower levels of cell death population after co-treatment with 4-PMPB, 4-EMPB or 4-MMPB compounds and deferoxamine, compared with those treated with the compounds only, it is proposed that cell death is triggered through both apoptosis and ferroptosis pathways. It has been shown that $A L O X 15$ expression is regulated by a mutant form of $P 53$ and results in promoting PC [58]. Moreover, 13S-HODE, the major metabolite of 15-LOX-1 can interact with anti-apoptotic mediators such as B-cell lymphoma 2 (BCL2) and insulin-like growth factor receptor-1 (IGF-1R) which leads to inhibition of apoptotic signaling pathways in PC [59-61]. Additionally, recent studies demonstrated that $15-\mathrm{LOX}-1$ is one of the fundamental regulators in ferroptosis pathway 
$\mathbf{a}$

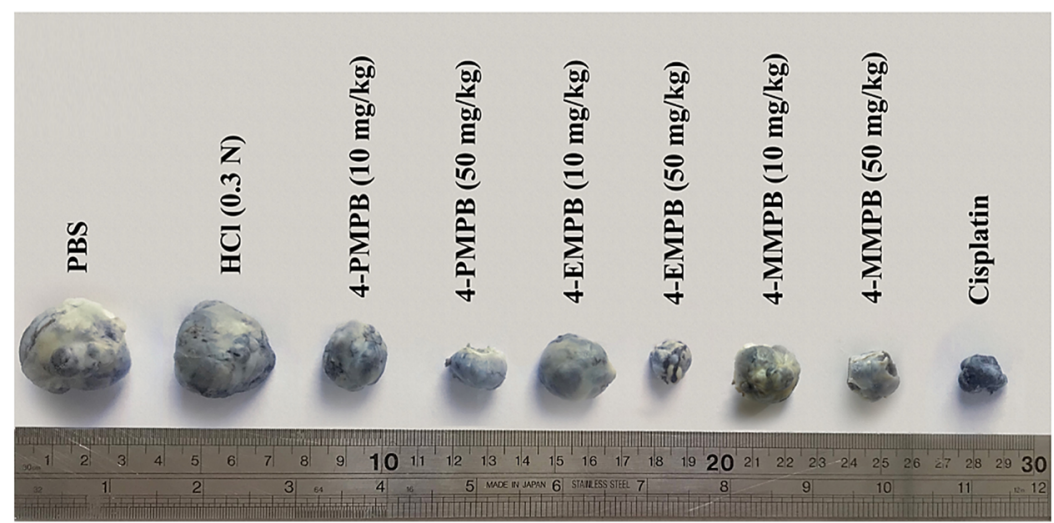

b

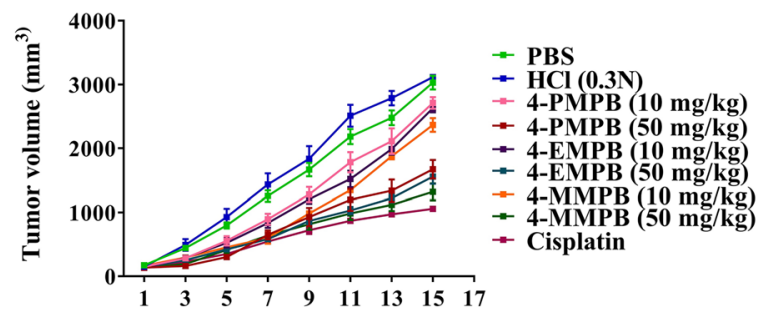

d

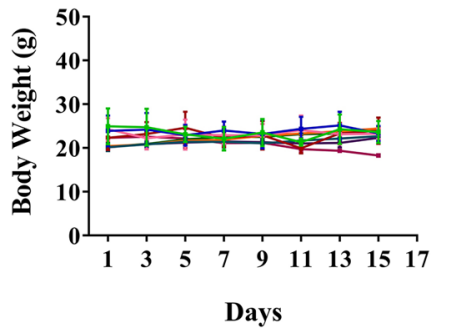

c

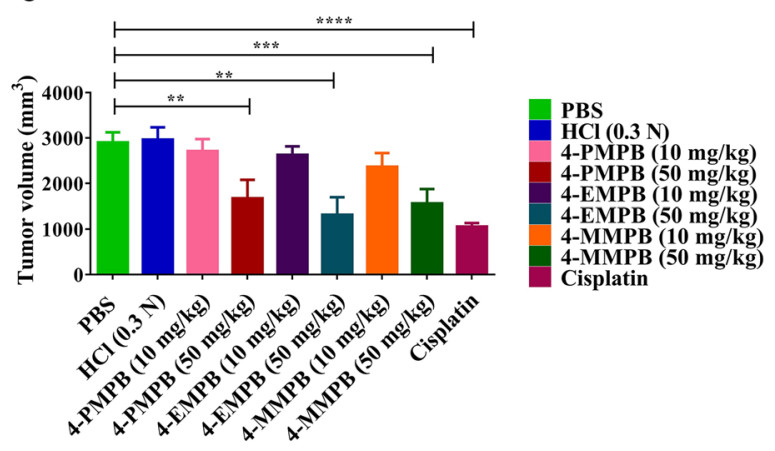

e

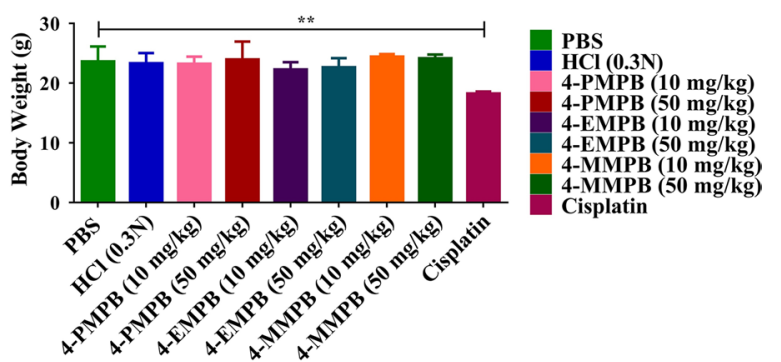

Fig. 6 In vivo therapeutic efficacy of 4-PMPB, 4-EMPB and 4-MMPB on immunocompromised C57BL/6 mice bearing PC-3 tumors. a Representative image of tumors at day 15 after various treatments. b Tumor growth curves indicated, cisplatin and high doses of 4-PMPB, 4-EMPB and 4-MMPB had remarkable anti-tumor effects during the 15 days of treatments. $\mathbf{c}$ At the end of the experiment, tumor volumes were measured and significant differences were observed between the PBS and $\mathrm{HCl}$ controls and those treated with $50 \mathrm{mg} \mathrm{kg}^{-1}$ of the compounds as well as cisplatin groups. $\mathbf{d}$ The body weights of different groups were continuously evaluated during the 15 days follow up. e There was a significant difference in body weight loss between cisplatin and other treatment groups on day 15. Data are expressed as mean $\pm \mathrm{SD}, \mathrm{n}=8 .{ }^{* *} p<0.01,{ }^{* * *} p<0.001$ and ${ }^{* * * *} p<0.0001$

$[44,62]$, and is involved in PUFA oxidation and pro-ferroptotic lipid peroxide generation [63]. In order to better evaluate the efficacy of anti-cancer agents, treatment strategy should also be assessed in animal experimental models [64, 65]. Nude and immunocompromised mice models are commonly used as hosts for human cancer cell lines. However, nude mice bear several drawbacks due to high cost, low tumorigenesis rate, high sensitivity, difficult maintenance and high mortality rate [66]; therefore we used immunocompromised mice bearing human PC as a preferred model. There are a number of immunosuppressive medications such as glucocorticoids, azathioprine, cyclophosphamide, methotrexate, cyclosporine, ketoconazole and tacrolimus which are used 

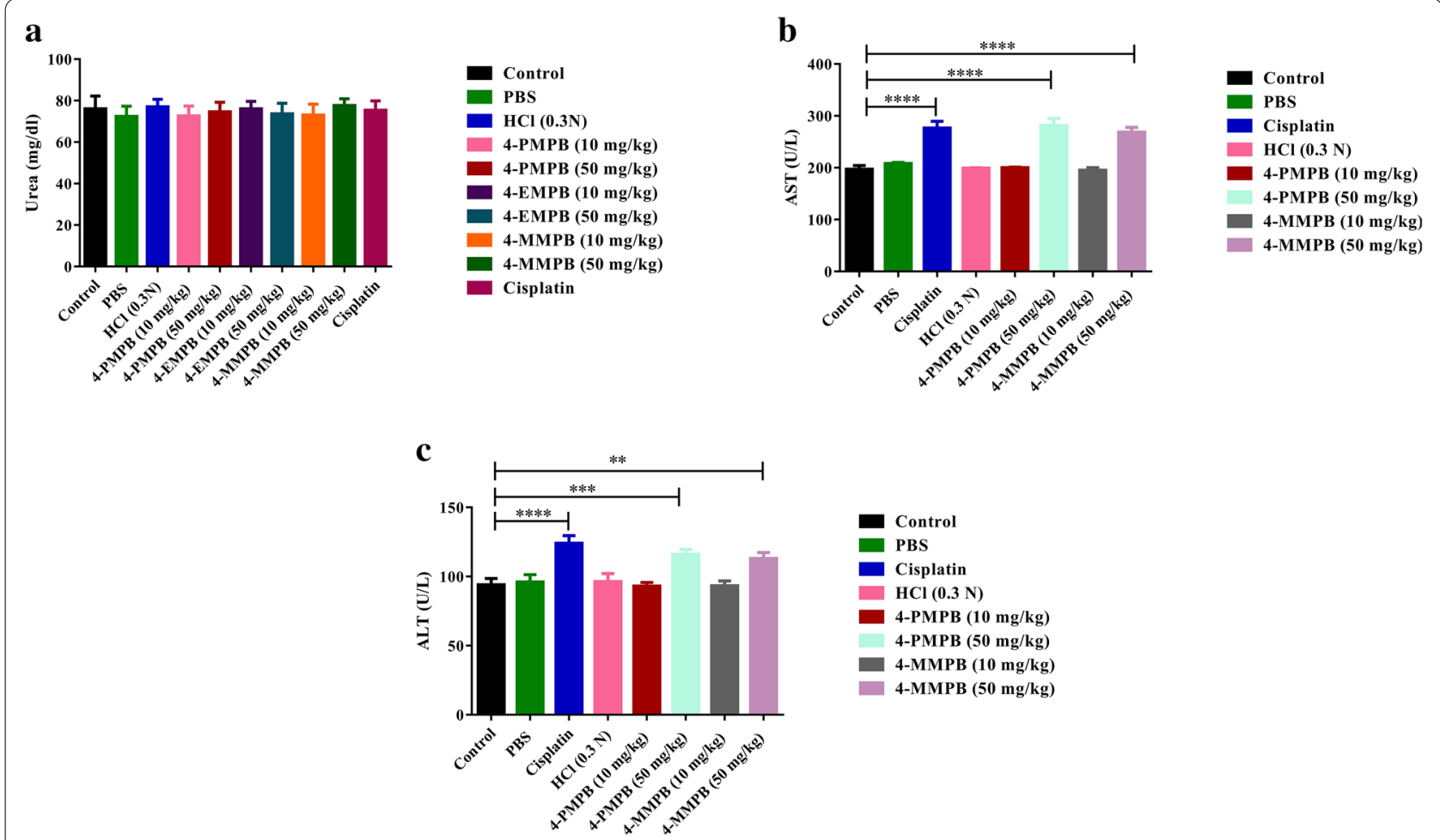

Fig. 7 Effects of different treatments on serum biochemical parameters including $\mathbf{a}$ urea, $\mathbf{b}$ aspartate transaminase (AST) and $\mathbf{c}$ alanine aminotransferase (ALT). Data are expressed as mean $\pm S D, n=3,{ }^{* *} p<0.01,{ }^{* *} p<0.001$ and ${ }^{* * *} p<0.0001$

alone or in combination to prevent human tumor xenografts rejection in murine models [64]. Cunha et al. [67] reported xenotransplantation of human glioblastoma cells in rats by cyclosporine treatment $(5 \mathrm{mg}$ per $\mathrm{kg}$ per day) until the end of experiments. Similarly, Du et al. [68] reported use of cyclosporine treatment $(10 \mathrm{mg}$ per $\mathrm{kg}$ per day) for development of human hepatocarcinoma cells xenograft in a C57BL/6 mouse model. Moreover, Rose et al. [69] reported that xenologous skin transplantation in an immunosuppressed sheep model was made possible by using cyclosporine $\left(2-3 \mathrm{mg} \mathrm{kg}^{-1}\right)$ in combination with ketoconazole $\left(10 \mathrm{mg} \mathrm{kg}^{-1}\right)$ after 18 days. In present study, human PC xenograft was developed according to the Jivrajani's protocol in C57BL/6 mice [51]. Blood count analysis after administration of immunosuppression protocol, and tumor growth volume in control groups confirmed successful immunosuppression and xenotransplantation in mouse model. Moreover, in vivo results demonstrated that while cisplatin treatment led to a significant decrease in tumor size, it suffered from side effects including a significant decrease in body weight. Furthermore, the highest dose of 4-PMPB and 4-EMPB $\left(50 \mathrm{mgkg}^{-1}\right)$ possessed similar anti-cancer effects as compared with 4-MMPB, leading to delayed tumor growth without noticeable side effects in weight loss and histological assessments.

\section{Conclusion}

Targeted therapeutic strategies such as lipoxygenase inhibition in PC can reduce tumor growth and help in improving clinical outcomes. Data generated from our study showed that, use of 4-PMPB and 4-EMPB can be considered as a treatment of choice to trigger both apoptosis and ferroptosis pathways and inhibit PC cell survival in vitro and in vivo probably via specific targeting of lipoxygenases. For this purpose, different approaches can be recommended, and use of nanotechnology-based drug delivery systems (DDSs) is one of the most attractive strategies. In this regard, mentioned compound inhibitors of lipoxygenases can be encapsulated into specific 


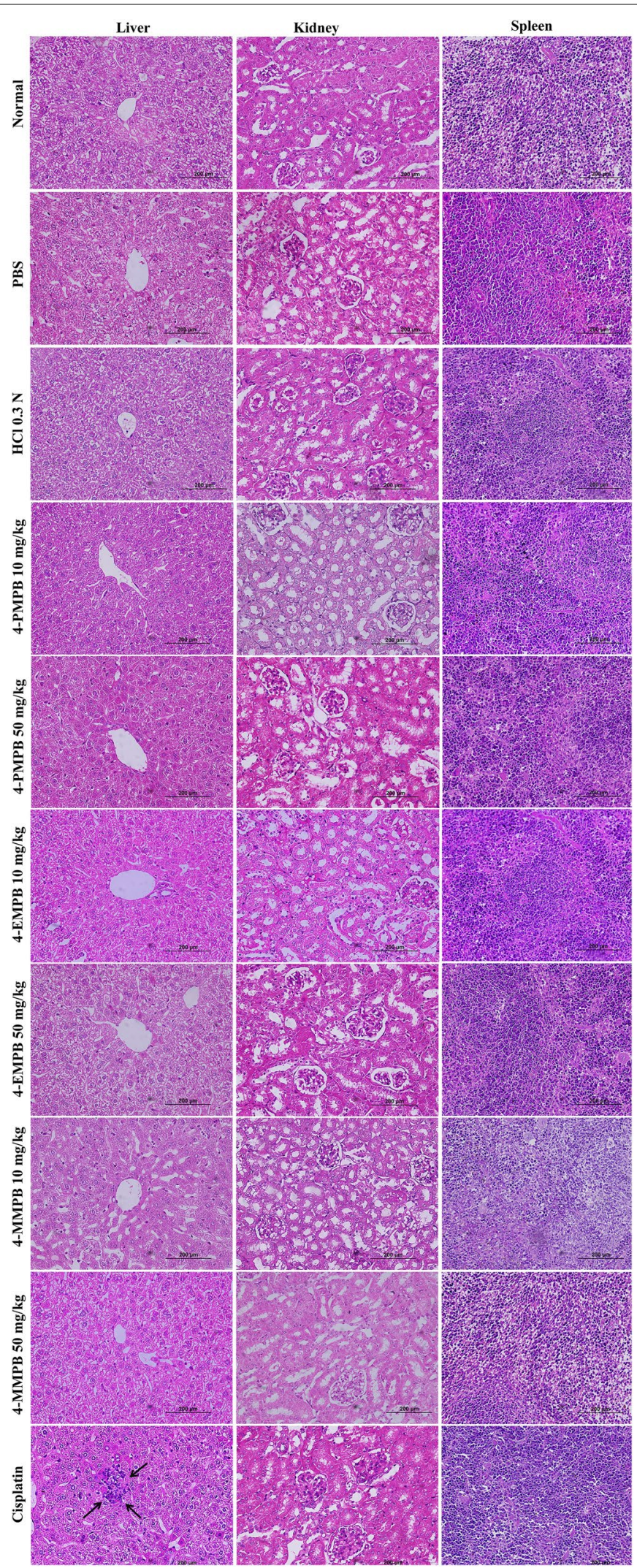

Fig. 8 Hematoxylin and eosin (H\&E)-stained images of major organs (liver, kidney, and spleen) collected on day 15 after treatments. Mild and local accumulation of inflammatory cells was noticed in cisplatin treated group (black arrows). Scale bar: $200 \mu \mathrm{m}$ 

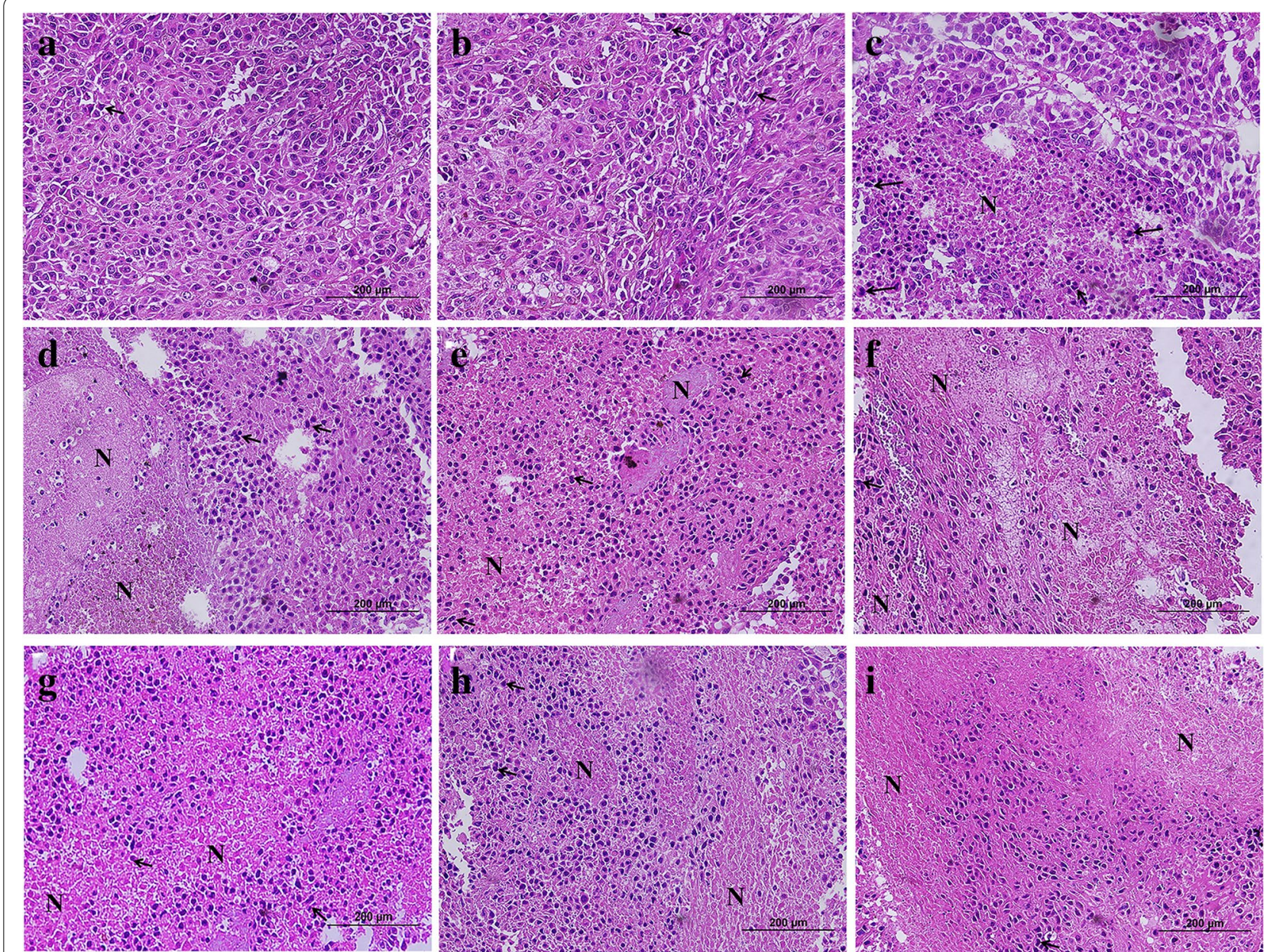

Fig. 9 Hematoxylin and eosin ( $\mathrm{H} \&$ E)-stained images of tumor tissues upon different experimental conditions: a PBS, b $0.3 \mathrm{~N} \mathrm{HCl}, \mathbf{c} 4-\mathrm{PMPB}$ $\left(10 \mathrm{mg} \mathrm{kg}^{-1}\right)$, d 4-PMPB $\left(50 \mathrm{mg} \mathrm{kg}^{-1}\right)$, e 4-EMPB $\left(10 \mathrm{mg} \mathrm{kg}^{-1}\right)$, f 4-EMPB $\left(50 \mathrm{mg} \mathrm{kg}^{-1}\right), \mathbf{g} 4-\mathrm{MMPB}\left(10 \mathrm{mg} \mathrm{kg}^{-1}\right), \mathbf{h}$ 4-MMPB $\left(50 \mathrm{mg} \mathrm{kg}{ }^{-1}\right)$ and i cisplatin. Black arrows and " $\mathrm{N}$ " represent mitotic figures and necrotic areas, respectively within the tumor mass. Scale bar: $200 \mu \mathrm{m}$

nanocarriers such as liposomes, which would enable us to use them in clinical trials. Moreover, surface of nanocarriers can be decorated with specific ligands referred as active targeting, to reduce possible side effects on normal tissues and facilitate their availability to tumor microenvironment.

\footnotetext{
Abbreviations

uM: Micromolar; 4-EMPB: 4-Ethyl-2-(4-methylpiperazinyl)pyrimido[4,5-b] benzothiazine; 13-HpODE: 13-Hydroperoxyoctadecadienoic acid; 13-HODE: 13-Hydroxyoctadecadienoic acid; 15-HpETE: Hydroperoxyeicosatetraenoic acid; 15-HETE: Hydroxyeicosatetraenoic acid; 15-LOX-1: 15-Lipoxygenase-1; 15-LOX-2: 15-Lipoxygenase-2; 4-MMPB: 4-Methyl-2-(4-methylpiperazinyl) pyrimido[4,5-b]benzothiazine; 4-PMPB: 4-Propyl-2-(4-methylpiperazinyl) pyrimido[4,5-b]benzothiazine; AA: Arachidonic acid; DMEM: Dulbecco's modified Eagle's medium; DMSO: Dimethyl sulfoxide; FBS: Fetal bovine serum; H\&E: Hematoxylin \& Eosin; HCl: Hydrochloric acid; HDF: Human dermal fibroblast; $\mathrm{IC}_{50}$ : Half maximal inhibitory concentration; IGF-1: Insulin-like growth factor-1; MTT: 3-(4,5-Dimethylthiazol-2-yl)-2,5-diphenyltetrazolium bromide; SD: Standard deviation.
}

\section{Acknowledgements}

The authors would like to thank Dr. Noroozpour Laboratory for their great technical help with tissue processing. We sincerely thank Dr. Haniyeh Shaterzade for her excellent histological analysis and also Miss. Tayebe Moghaddam for her kind technical assistance in animal studies.

\section{Authors' contributions}

SI and AKMAM conducted the methodology and inferences, carried out the statistical analyses, and wrote the manuscript. ARB had financial support and proofread the manuscript. HS carried out the chemical synthesis and performed lipoxygenase inhibitory assessment. MMM conceived the original idea and designed the study, had financial support, analyzed the results, and wrote the manuscript. All authors read and approved the final manuscript.

\section{Funding}

This work was supported by the Ferdowsi University of Mashhad, Grant Numbers: 51537 and 51720 . 


\section{Declarations}

\section{Ethics approval and consent to participate}

The animal experiments were approved and conducted in accordance with Animal Ethics Committee of Ferdowsi University of Mashhad (IR. UM.REC.1399.001)

\section{Consent for publication}

Not applicable for this section.

\section{Competing interests}

The authors declare that they have no competing interests.

\section{Author details}

'Department of Biology, Faculty of Science, Ferdowsi University of Mashhad, Mashhad, Iran. ${ }^{2}$ Department of Biology, Faculty of Science, University of Thi-Qar, Nasiriyah, Iraq. ${ }^{3}$ Industrial Biotechnology Research Group, Institute of Biotechnology, Ferdowsi University of Mashhad, Mashhad, Iran. ${ }^{4}$ Applied Biomedical Research Center, Department of Laboratory Sciences, School of Paramedical Sciences, Mashhad University of Medical Sciences, Mashhad, Iran. ${ }^{5}$ Novel Diagnostics and Therapeutics Research Group, Institute of Biotechnology, Ferdowsi University of Mashhad, Mashhad, Iran.

Received: 10 November 2020 Accepted: 16 April 2021 Published online: 04 May 2021

\section{References}

1. Pernar CH, Ebot EM, Wilson KM, Mucci LA. The epidemiology of prostate cancer. Cold Spring Harb Perspect Med. 2018;8:a030361.

2. Robles LA, Wright SJ, Hackshaw-McGeagh L, Shingler E, Shiridzinomwa C, Lane JA, Martin RM, Burden S. Prostate cancer survivors' preferences on the delivery of diet and lifestyle advice: a pilot best-worst discrete choice experiment. Pilot Feasibility Stud. 2020;6:1-9.

3. Sokoła-Wysoczańska E, Wysoczański T, Wagner J, Czyż K, Bodkowski R, Lochyński S, Patkowska-Sokoła B. Polyunsaturated fatty acids and their potential therapeutic role in cardiovascular system disorders - a review. Nutrients. 2018;10:1561

4. Tallima H, El Ridi R. Arachidonic acid: physiological roles and potential health benefits - a review. J Adv Res. 2018;11:33-41.

5. Radzikowska U, Rinaldi AO, Çelebi Sözener Z, Karaguzel D, Wojcik M, Cypryk K, Akdis M, Akdis CA, Sokolowska M. The influence of dietary fatty acids on immune responses. Nutrients. 2019;11:2990.

6. Long J, Zhang C-J, Zhu N, Du K, Yin Y-F, Tan X, Liao DF, Qin L. Lipid metabolism and carcinogenesis, cancer development. Am J Cancer Res. 2018:8:778-91.

7. Fleshner N, Bagnell PS, Klotz L, Venkateswaran V. Dietary fat and prostate cancer. J Urol. 2004;171:S19-24.

8. Williams CD, Whitley BM, Hoyo C, Grant DJ, Iraggi JD, Newman KA, Gerber L, Taylor LA, McKeever MG, Freedland SJ. A high ratio of dietary n-6/n-3 polyunsaturated fatty acids is associated with increased risk of prostate cancer. Nutr Res. 2011;31:1-8.

9. Cho HJ, Kwon GT, Park H, Song H, Lee KW, Kim J-I, Park JH. A high-fat diet containing lard accelerates prostate cancer progression and reduces survival rate in mice: possible contribution of adipose tissue-derived cytokines. Nutrients. 2015;7:2539-61.

10. Hu MB, Xu H, Zhu WH, Bai PD, Hu JM, Yang T, Jiang HW, Ding Q. High-fat diet-induced adipokine and cytokine alterations promote the progression of prostate cancer in vivo and in vitro. Oncol Lett. 2018;15:1607-15.

11. Day SD, Enos RT, McClellan JL, Steiner J, Velázquez KT, Murphy E. Linking inflammation to tumorigenesis in a mouse model of high-fat-dietenhanced colon cancer. Cytokine. 2013:64:454-62.

12. O'Neill AM, Burrington CM, Gillaspie EA, Lynch DT, Horsman MJ, Greene MW. High-fat Western diet-induced obesity contributes to increased tumor growth in mouse models of human colon cancer. Nutr Res. 2016:36:1325-34.

13. Mustafi D, Fernandez S, Markiewicz E, Fan X, Zamora M, Mueller J, Brady MJ, Conzen SD, Karczmar GS. MRI reveals increased tumorigenesis following high fat feeding in a mouse model of triple-negative breast cancer. NMR Biomed. 2017;30:e3758.

14. Zhu Y, Aupperlee MD, Haslam SZ, Schwartz RC. Pubertally initiated highfat diet promotes mammary tumorigenesis in obesity-prone FVB mice similarly to obesity-resistant BALB/c mice. TransI Oncol. 2017;10:928-35.

15. Nie D. Cyclooxygenases and lipoxygenases in prostate and breast cancers. Front Biosci. 2007:12:1574-85.

16. Fürstenberger $G$, Krieg P, Müller-Decker K, Habenicht A. What are cyclooxygenases and lipoxygenases doing in the driver's seat of carcinogenesis? Int J Cancer. 2006;119:2247-54.

17. Shappell SB, Boeglin WE, Olson SJ, Kasper S, Brash AR. 15-lipoxygenase-2 (15-LOX-2) is expressed in benign prostatic epithelium and reduced in prostate adenocarcinoma. Am J Pathol. 1999;155:235-45.

18. Gohara A, Eltaki N, Sabry D, Murtagh D, Jankun J, Selman SH, SkrzypczakJankun E. Human 5, 12-and 15-lipoxygenase-1 coexist in kidney but show opposite trends and their balance changes in cancer. Oncol Rep. 2012;28:1275-82

19. Nixon JB, Kim KS, Lamb PW, Bottone FG, Eling TE. 15-Lipoxygenase-1 has anti-tumorigenic effects in colorectal cancer. Prostaglandins Leukot Essent Fatty Acids. 2004:70:7-15.

20. Shureiqi I, Wu Y, Chen D, Yang XL, Guan B, Morris JS, Yang P, Newman RA, Broaddus R, Hamilton SR, Lynch P, Levin B, Fischer SM, Lippman SM. The critical role of 15-lipoxygenase-1 in colorectal epithelial cell terminal differentiation and tumorigenesis. Cancer Res. 2005;65:11486-92.

21. Yuan H, Li M-Y, Ma LT, Hsin MK, Mok TS, Underwood MJ, Chen GC. 15-Lipoxygenases and its metabolites 15 (S)-HETE and 13 (S)-HODE in the development of non-small cell lung cancer. Thorax. 2010;65:321-6.

22. Shureiqi I, Xu X, Chen D, Lotan R, Morris JS, Fischer SM, Lippman SM. Nonsteroidal anti-inflammatory drugs induce apoptosis in esophageal cancer cells by restoring 15-lipoxygenase-1 expression. Cancer Res. 2001:61:4879-84

23. Philips BJ, Dhir R, Hutzley J, Sen M, Kelavkar UP. Polyunsaturated fatty acid metabolizing 15-lipoxygenase-1 (15-LO-1) expression in normal and tumorigenic human bladder tissues. Appl Immunohistochem Mol Morphol. 2008;16:159-64.

24. Middleton MK, Zukas AM, Rubinstein T, Jacob M, Zhu P, Zhao L, Blair I, Puré E. Identification of 12/15-lipoxygenase as a suppressor of myeloproliferative disease. J Exp Med. 2006:203:2529-40.

25. Snodgrass RG, Brüne B. Regulation and functions of 15-lipoxygenases in human macrophages. Front Pharmacol. 2019;10:719.

26. Jack GS, Brash AR, Olson SJ, Manning S, Coffey CS, Smith JA, Shappell SB. Reduced 15-lipoxygenase-2 immunostaining in prostate adenocarcinoma: correlation with grade and expression in high-grade prostatic intraepithelial neoplasia. Hum Pathol. 2000;31:1146-54.

27. Gonzalez AL, Roberts RL, Massion PP, Olson SJ, Shyr Y, Shappell SB. 15-Lipoxygenase-2 expression in benign and neoplastic lung: an immu nohistochemical study and correlation with tumor grade and proliferation. Hum Pathol. 2004;35:840-9.

28. Xu XC, Shappell SB, Liang Z, Song S, Menter D, Subbarayan V, lyengar S, Tang DG, Lippman SM. Reduced 15S-lipoxygenase-2 expression in esophageal cancer specimens and cells and upregulation in vitro by the cyclooxygenase-2 inhibitor, NS398. Neoplasia. 2003;5:121-7.

29. Brash AR, Boeglin WE, Chang MS. Discovery of a second 15S-lipoxygenase in humans. Proc Natl Acad Sci USA. 1997;94:6148-52.

30. Ghosh J, Myers CE. Arachidonic acid stimulates prostate cancer cell growth: critical role of 5-lipoxygenase. Biochem Biophys Res Commun. 1997:235:418-23.

31. Pidgeon GP, Kandouz M, Meram A, Honn KV. Mechanisms controlling cell cycle arrest and induction of apoptosis after 12-lipoxygenase inhibition in prostate cancer cells. Cancer Res. 2002:62:2721-7.

32. Matsuyama M, Yoshimura R, Mitsuhashi M, Hase T, Tsuchida K, Takemoto Y, Kawahito Y, Sano H, Nakatani T. Expression of lipoxygenase in human prostate cancer and growth reduction by its inhibitors. Int J Oncol. 2004;24:821-7.

33. Hosseinymehr M, Matin MM, Sadeghian H, Bahrami AR, Kaseb-Mojaver N. 8-Farnesyloxycoumarin induces apoptosis in PC-3 prostate cancer cells by inhibition of 15-lipoxygenase-1 enzymatic activity. Anticancer Drugs. 2016:27:854-62.

34. Orafaie A, Sadeghian H, Bahrami AR, Saboormaleki S, Matin MM. 5-farnesyloxycoumarin: a potent 15-LOX-1 inhibitor, prevents prostate cancer cell growth. Med Chem Res. 2017;26:227-34. 
35. Saboormaleki S, Sadeghian H, Bahrami AR, Orafaie A, Matin MM. 7-farnesyloxycoumarin exerts anti-cancer effects on a prostate cancer cell line by 15-LOX-1 inhibition. Arch Iran Med. 2018;21:251-9.

36. Goftari SN, Sadeghian H, Bahrami AR, Maleki F, Matin MM. Stylosin and some of its synthetic derivatives induce apoptosis in prostate cancer cells as 15-lipoxygenase enzyme inhibitors. Naunyn Schmiedebergs Arch Pharmacol. 2019;392:1491-502.

37. Eleftheriadis N, Neochoritis CG, Leus NG, van der Wouden PE, Domling A, Dekker FJ. Rational development of a potent 15-lipoxygenase-1 inhibitor with in vitro and ex vivo anti-inflammatory properties. J Med Chem. 2015;58:7850-62.

38. ElBordiny HS, El-Miligy MM, Kassab SE, Daabees H, Ali WAM, El-Hawash SAM. Design, synthesis, biological evaluation and docking studies of new 3-(4, 5-dihydro-1H-pyrazol/isoxazol-5-yl)-2-phenyl-1H-indole derivatives as potent antioxidants and 15-lipoxygenase inhibitors. Eur J Med Chem. 2018;145:594-605.

39. Guo H, Verhoek IC, Prins GG, van der Vlag R, van der Wouden PE, van Merkerk R, et al. Novel 15-lipoxygenase-1 inhibitor protects macrophages from lipopolysaccharide-induced cytotoxicity. J Med Chem. 2019;62:4624-37

40. Sarveswaran S, Thamilselvan V, Brodie C, Ghosh J. Inhibition of 5-lipoxygenase triggers apoptosis in prostate cancer cells via down-regulation of protein kinase C-epsilon. Biochim Biophys Acta. 2011;1813:2108-17.

41. Sarveswaran S, Chakraborty D, Chitale D, Sears R, Ghosh J. Inhibition of 5-lipoxygenase selectively triggers disruption of c-Myc signaling in prostate cancer cells. J Biol Chem. 2015;290:4994-5006

42. Lövey J, Nie D, Tóvári J, Kenessey I, Kandouz M, Tímár J, et al. Selective 12-lipoxygenase inhibition potentiates the effect of radiation on human prostate cancer cells in vitro and in vivo. Magy Onkol. 2014;58:211-8.

43. Lövey J, Nie D, Tóvári J, Kenessey I, Tímár J, Kandouz M, et al. Radiosensitivity of human prostate cancer cells can be modulated by inhibition of 12-lipoxygenase. Cancer Lett. 2013;335:495-501.

44. Shah R, Shchepinov MS, Pratt DA. Resolving the role of lipoxygenases in the initiation and execution of ferroptosis. ACS Cent Sci. 2018;4:387-96.

45. Yang X, Liu J, Wang C, Cheng KK, Xu H, Li Q, et al. miR-18a promotes glioblastoma development by down-regulating ALOXE3-mediated ferroptotic and anti-migration activities. Oncogenesis. 2021;10:15.

46. Bakavoli M, Nikpour M, Rahimizadeh M, Saberi M, Sadeghian H. Design and synthesis of pyrimido $[4,5-b][1,4]$ benzothiazine derivatives, as potent 15-lipoxygenase inhibitors. Bioorg Med Chem. 2007;15:2120-6.

47. Nikpour M, Mousavian M, Davoodnejad M, Alimardani M, Sadeghian $H$. Synthesis of new series of pyrimido $[4,5-b][1,4]$ benzothiazines as 15-lipoxygenase inhibitors and study of their inhibitory mechanism. Med Chem Res. 2013;22:5036-43.

48. Mosmann T. Rapid colorimetric assay for cellular growth and survival: application to proliferation and cytotoxicity assays. J Immunol Methods. 1983:65:55-63.

49. Maleki EH, Bahrami AR, Sadeghian H, Matin MM. Discovering the structure-activity relationships of different O-prenylated coumarin derivatives as effective anticancer agents in human cervical cancer cells. Toxicol In Vitro. 2020;63:104745

50. Chen D, Eyupoglu IY, Savaskan N. Ferroptosis and cell death analysis by flow cytometry. Cell Viability Assays: Springer; 2017. p. 71-7.

51. Jivrajani M, Shaikh MV, Shrivastava N, Nivsarkar M. An improved and versatile immunosuppression protocol for the development of tumor xenograft in mice. Anticancer Res. 2014;34:7177-83.

52. Li Y, Duo Y, Zhai P, He L, Zhong K, Zhang Y, et al. Dual targeting delivery of miR-328 by functionalized mesoporous silica nanoparticles for colorectal cancer therapy. Nanomedicine. 2018;13:1753-72.

53. Nurgali K, Jagoe RT, Abalo R. Adverse effects of cancer chemotherapy: Anything new to improve tolerance and reduce sequelae? Front Pharmacol. 2018;9:245.
54. Siegel RL, Miller KD, Jemal A. Cancer statistics, 2019. CA Cancer J Clin. 2019;69:7-34.

55. Mashima R, Okuyama T. The role of lipoxygenases in pathophysiology; new insights and future perspectives. Redox Biol. 2015;6:297-310.

56. Chen B, Tsui S, Boeglin WE, Douglas RS, Brash AR, Smith TJ. Interleukin-4 induces 15-lipoxygenase-1 expression in human orbital fibroblasts from patients with graves disease: evidence for anatomic site-selective actions of Th2 cytokines. J Biol Chem. 2006;281:18296-306.

57. Simard-Bisson C, Parent LA, Moulin VJ, Fruteau de Laclos B. Characterization of epidermal lipoxygenase expression in normal human skin and tissue-engineered skin substitutes. J Histochem Cytochem. 2018;66:813-24.

58. Kelavkar U, Glasgow W, Eling TE. The effect of 15-lipoxygenase-1 expression on cancer cells. Curr Urol Rep. 2002;3:207-14.

59. DiGiovanni J, Kiguchi K, Frijhoff A, Wilker E, Bol DK, Beltrán L, et al. Deregulated expression of insulin-like growth factor 1 in prostate epithelium leads to neoplasia in transgenic mice. Proc Natl Acad Sci USA. 2000;97:3455-60.

60. Maccarrone M, Melino G, Finazzi-Agro A. Lipoxygenases and their involvement in programmed cell death. Cell Death Differ. 2001;8:776-84.

61. Kuhn H, Banthiya S, Van Leyen K. Mammalian lipoxygenases and their biological relevance. Biochim Biophys Acta. 2015;1851:308-30.

62. Tousignant KD, Rockstroh A, Poad BL, Talebi A, Young RS, Fard AT, et al. Therapy-induced lipid uptake and remodeling underpin ferroptosis hypersensitivity in prostate cancer. Cancer Metab. 2020;8:11.

63. Yang WS, Kim KJ, Gaschler MM, Patel M, Shchepinov MS, Stockwell BR. Peroxidation of polyunsaturated fatty acids by lipoxygenases drives ferroptosis. Proc Natl Acad Sci USA. 2016;113:4966-75.

64. Diehl R, Ferrara F, Müller C, Dreyer AY, McLeod DD, Fricke S, et al. Immunosuppression for in vivo research: state-of-the-art protocols and experimental approaches. Cell Mol Immunol. 2017;14:146-79.

65. Okada S, Vaeteewoottacharn K, Kariya R. Application of highly immunocompromised mice for the establishment of patient-derived xenograft (PDX) models. Cells. 2019;8:889-99.

66. Szadvari I, Krizanova O, Babula P. Athymic nude mice as an experimental model for cancer treatment. Physiol Res. 2016;65:441-53.

67. Cunha AM, Nascimento FS, Amaral JC, Konig S, Takiya CM, Neto VM, et al. A murine model of xenotransplantation of human glioblastoma with imunosupression by orogastric cyclosporin. Arq Neuropsiquiatr. 2011;69:112-7.

68. Du X, Bai Z, Zhang J, Liu L, Han Y, Wang Z, et al. Prolonged survival of human hepatocarcinoma cells in the liver of newborn C57BL/6 mice and resulting cellular xenorejection, especially the activation of hepatic natural killer T cells. Pathobiology. 2010;77:115-28.

69. Rose A, llett K, O'Donoghue H, Hackett L, Penhale W, Manning L, et al. Cyclosporin immunosuppression of sheep: pharmacokinetics and allograft survival. Vet Immunol Immunopathol. 2001;81:23-36.

\section{Publisher's Note}

Springer Nature remains neutral with regard to jurisdictional claims in published maps and institutional affiliations.

Ready to submit your research? Choose BMC and benefit from:

- fast, convenient online submission

- thorough peer review by experienced researchers in your field

- rapid publication on acceptance

- support for research data, including large and complex data types

- gold Open Access which fosters wider collaboration and increased citations

- maximum visibility for your research: over $100 \mathrm{M}$ website views per year

At BMC, research is always in progress.

Learn more biomedcentral.com/submissions 